\title{
Policing for commodification: turning communicative resources into commodities
}

\author{
Sebastian Muth ${ }^{1}$ Alfonso Del Percio ${ }^{2}$
}

Received: 23 May 2017/ Accepted: 26 May 2017/Published online: 29 June 2017

(C) Springer Science+Business Media B.V. 2017

Keywords Language policing - Commodification of languages and speakers · Language management $\cdot$ Political economy

Scholarly production in language policy has recently turned to the Foucault (2007) concept of policing in order to enhance our explication of the way language and speakers are controlled, disciplined and regulated according to morally marked understandings of language, society and the self (see e.g. Blommaert et al. 2009). Breaking with modernist conceptualizations of language in society (Fishman 1991), in the last decades policing has been used to problematize the ways individuals and actors express control over their own communicative conduct as well as over the languages, behaviors and bodies of others (see e.g. Duchêne 2009; McNamara 2012; Piller and Cho 2013; Wee 2015). This way of understanding the governmentality of language (Martin-Rojo 2016) does not just ask us to rethink the workings of power and its effects on speakers, institutions and polities, it also urges us to re-center our analytical focus on the tokens of expertise that inform and naturalize the processes of linguistic policing as well as the particular practices through which this knowledge acts on individuals. Further it forces us to resituate the language policy within the material conditions of language and social life (Del Percio et al. 2016).

Sebastian Muth

sebastian.muth@unifr.ch

Alfonso Del Percio

alfonso.delpercio@gmail.com

1 Institute of Multilingualism, University of Fribourg, Rue de Morat 24, 1700 Fribourg, Switzerland

2 Centre for Applied Linguistics, UCL Institute of Education, University College London, 20 Bedford Way, London WC1H 0AL, UK 
This special issue 'Policing for commodification: turning communicative resources into commodities' aims to expand our understanding of linguistic policing by engaging in a conversation about the regulatory processes that are at work when languages and speakers are recast as and turned into commodities. Recent sociolinguistic scholarship has taken different settings such as the workplace, marketing, tourism, education as well as art as starting points in order to demonstrate how and with what effects language can be exchanged for various forms of capital gain on specific markets (Cameron 2012; Heller and Duchêne 2016; Tan and Rubdy 2008). This body of research has become increasingly interested in the commodity value of languages, looking at ways to imagine, disentangle, analyze and making sense of the complex relationship between communicative resources and their potential economic value. According to this scholarship, languages as commodities play a double role: Language and multilingualism may serve to imbue a given product, place or person with specific qualities (for instance being authentic, local, exotic, sexy, serious, as well as professional, progressive, or cosmopolitan) that a given language is usually associated with and that are considered as particularly desirable by certain consumers (Bishop et al. 2005; Blommaert 2009; Cavanaugh and Shankar 2014; Kelly-Holmes 2005; Piller 2007). Also, language and multilingualism can be regarded as powerful resources serving the conduct of specific work tasks and playing central roles in the management of complex networks and the circulation of knowledge (Cameron 2000; Duchêne 2011; Pavlenko 2017).

Along with this literature, scholars have examined the market conditions under which language can be turned into an economic resource (Kelly-Holmes 2016; McGill 2013). Research has also problematized linguists' logocentrism and argued that the commodification of language is part of larger exploitative processes involving the commodification of individuals producing language (Holborow 2015). Finally scholars have pointed to the necessity to resonate with Marxist theory (Block forthcoming) and language economics (Grin and Vaillancourt 2012) to expand our understanding of the processes that are at play when language is turned into a commodity.

In foregrounding the interrelationship between language, commodity value and practices of policing, this special issue engages with this ongoing debate on the commodification of language by a set of contributions examining the specific rhetoric and process through which languages and speakers are policed, i.e. controlled and regulated in order to be turned into commodifiable objects. We aim to expand our understanding of language commodification and incorporate a perspective that highlights the circumstances and processes in which potential commodity values are negotiated, decided upon and made possible. We examine how the commodity value of specific communicative resources is discursively constructed and identified by both individuals and institutional actors and how turning communicative resources into commodities links to discourses of order and sameness (Bauman and Briggs 2003), both shifting and at the same time reinforcing political economic conditions (Duchêne and Heller 2012; Pietikäinen and KellyHolmes 2013) as well as wider issue linked to the governmentality of selves and social life (Foucault 2000). 
Thus, this special issue intends to emphasize a perspective on language and commodification that examines processes, policies and decisions within different types of public and private organizations as well as communities and actors. In particular, we are bringing together six case studies documenting attempts to invest in forms of commodification of languages and speakers within six different national contexts (Switzerland, Italy, Ireland, Belgium, Pakistan and Tajikistan) and specific fields (medical tourism, heritage tourism, vocational training, minority language activism, the media, and language learning within transnational communities). All of them represent projects and agendas where investments in language commodification are made, following economic logics, being part of efforts of community building, language revitalization or incentives to create 'good' citizens. Indeed, we agree that the commodification of language is often anchored in processes of economic-development, -restructuring, and market expansion. However, in this special issue we are also interested in pointing to alternative histories and circumstances that prompt individuals, communities and organizations alike to engage in efforts to commodify languages and communicative resources. Concretely, this means that we examine the effects of current neoliberal rationales and logics for the ways language and speakers are framed and regulated, and in the same time resituate the policing and disciplining languages in longer histories of societal control and securitization. By doing so, it is our aim to raise awareness for a broader interpretation of the framing of languages and speakers as commodities that are intrinsically linked to community building, social activism, and attempts to create forms of social cohesion as well as to turning individuals into economically selfresponsible and -sufficient subjects. In this sense we are interested in generating an understanding of language commodification that incorporates but in the same time goes beyond its economic dimension and that regards these discourses as attempts to regulate and structure society and to produce specific types of speakers and communities for a diverse set of goals.

Investments that follow economic logics and motifs are investigated by Del Percio, Muth, and Schedel. These contributions describe efforts to commodify languages, speakers and communicative conduct from diverse perspectives. In his ethnographic account of counseling practices in a state-run professional guidance center for newly arrived migrants to Italy, Del Percio highlights strategies to commodify a 'bundle of skills' that are mobilized to engineer commodifiable migrant workers for the Italian labor market. By describing how migrants' communicational conduct is policed and how their socialization into desirable professional selves is promoted, the paper sees efforts to commodify communicative resources both as expressions of a neoliberal logic of activation and professionalization, but at the same time also that of a civic engagement of counsellors that aims to emancipate migrants and turn them into self-reliant citizens. Yet ideas on what constitutes commodifiable communicative resources and desired speakers are not necessarily clear-cut. This aspect is taken up in Muth's paper on the commodification of language as a means to provide services for patients in the Swiss healthcare industry. Within this context the paper examines the management of multilingualism and the negotiation of the oftentimes fluctuating and unstable value of linguistic resources within two hospitals engaged in providing care for 
affluent Russian- and Arabic-speaking medical tourists. Specifically, the paper asks which linguistic proficiencies are deemed valuable, how this commodity value is constructed and how institutional policies react to changes in market conditions, imagining ideal medical workers with commodifiable communicative resources. Remaining within an economic logic of investing into speakers whose communicative resources represent an added value, Schedel's article examines the efforts to revive tourism in a small town situated on the language border between Frenchand German-speaking Switzerland. By analyzing the development and implementation of a bilingual guided theatrical tour within a community that only recently underwent structural economic change, the paper highlights how this tour is marketed as an expression of local bilingualism, how this bilingualism is enacted, and how it is turned into an experience sold to tourists.

Investments into language commodification as part of efforts of community building and the creation of social cohesion are described in contributions by Bolander, Brennan and Van Hoof. In her paper on transnationalism and the effects of an 'English as second language' policy on two Ismaili communities in Eastern Tajikistan and Northern Pakistan, Bolander demonstrates how English is discursively constructed as an economic and symbolic resource with language policy measures by the Aga Khan Education Services being used to underscore community-internal sameness and to create an transnational imagined Ismaili community (Anderson 1991). Similar efforts at community building but this time within the context of language revitalization efforts are described by Brennan in her paper on the promotion of Irish in the Republic of Ireland. This contribution particularly demonstrates how discourses of commodification are utilized to promote the use of Irish among small-scale business owners to contribute to the revitalization of Irish and in doing so help to constitute an imagined community of speakers. In the Belgian context, Van Hoof shows how attempts to turn speech styles of Dutch into a commercial resource by a public television broadcaster intersect with that organization's political concerns in educating and civilizing the Belgian nation.

Finally, investments into the creation of 'good' subjects and citizens are addressed in a number of contributions in this special issue. In her paper, Bolander describes how the mobilization of the idea of English as a valuable communicative resource is utilized to construct Ismaili community members as open to progress and globalization, while Del Percio highlights instances when language facilitates the commodification of labor power, with individuals being subjected to specific moral regimes aimed at turning them into 'good' citizens. Likewise, Muth refers to the idea that certain languages attract (wealthy/desirable) patients, as a consequence subjecting medical workers to normative orders that are not necessarily economically motivated. Ultimately this results in policies aiming to create appropriately skilled speakers who can be commodified on the global health market, in turn cumulating in the reproduction of stereotypical images of languages and speakers. From a broader perspective, Van Hoof's paper points towards efforts to apply ideas on the appropriate use of standard and nonstandard language use to a wider societal context.

All contributions dedicate particular analytical attention to the specific policing dynamics that underscore and inform attempts to reframe language as a commodity. Bolander's, Muth's, and Van Hoof's contribution highlight the top-down policing 
efforts aimed at producing marketable communicative resources via incentives for language learning, the discursive construction of competitive and potentially commodifiable language users, or the strategic utilization of language varieties in media broadcasts. These policing efforts are realized through the imposition of linguistic norms as part of spiritual guidance to the community (Bolander), the imposition of linguistic regimes within hospitals (Muth), or the imposition of specific normative modes of speaking by a public Belgian broadcaster (Van Hoof), in the latter case addressing both television producers and audiences being supposed to learn what 'good' and appropriate language is. Brennan and Schedel describe more subtle attempts at policing and refer to incentives that promise benefits in exchange for specific morally marked modes of speech. For Brennan this relates to the notion that language advocacy and limited revitalization efforts can prove to be profitable for small-town entrepreneurs, while in Schedel's case a carefully staged and policed imagination of a bilingual community may result both in a greater number of visitors as well as in capital gain for those engaged in the local tourism industry. In Del Percio's research, policing is exercised through demands on asylum seekers to work on themselves in order for them to be able to profit from the Italian labor market. Fundamentally, all policing of languages and speakers described in this special issue manifests a recurring trope in the field as scholars observe authorities exercising power and control over individuals and their communicative resources. At the same time though, we are also observing neoliberal modes in the regulation of speakers, calling for own initiatives to improve communicative conducts.

The effects of these regulatory discourses for languages and speakers come at a certain cost. Firstly, they put languages and speakers into specific hierarchies and effectively structure speakers depending on their communicative resources andconduct-while, secondly, they determine which languages are particularly suitable for communication and which are not. These effects are illustrated by Bolander with regard to English that is constructed as a highly valuable resource vis-à-vis regional (Russian and Urdu) as well as local languages (Burushaski and Tajik). Similar hierarchizations and metalinguistic discourses on use value become apparent in Del Percio's work. While proficiency in Italian is regarded as essential for a sustainable future within Italian society, all other languages of migrants are portrayed as being of little importance in the local economy; furthermore, hierarchies emerge that determine which personal properties count as favorable and desirable professional personas. In similar vein, Muth describes how changing market demands result in shifting values of linguistic repertoires, processes that in this instance are highlighted in a sudden devaluation of Arabic speakers and the emergence of a segmentation of speakers of Russian based on their linguistic and ethnic identities. In Brennan's and Schedel's research, idealized and authenticated visions of speakers and particular constellations of bilingual repertoires are brought forward, either in the form of English and Irish bilingualism or in that of a certain type of bilingual speaker mastering Swiss German and French. A hierarchization of standard and nonstandard Dutch is described by Van Hoof. Although an increased use of nonstandard forms of talk within television broadcasts led to an increasing overall use of nonstandard speech in the Belgian media, this nevertheless did not 
result in a wide societal shift in the perceptions of both standard and non-standard speech within the Dutch-speaking community in Belgium.

However, exclusion and the production and reproduction of social inequality are not the only effects of regulatory discourses on languages and speakers. While language commodification is frequently associated with processes of both objectification and alienation (Cameron 2000; Duchêne 2011), the papers within this special issue also show that the reframing of language as a commodity may also be a way to imagine alternative futures and promote societal change. In Del Percio's paper it helps individuals to find employment within a strained economy, whereas in Van Hoof's contribution, alternative forms of speech are popularized and made socially more acceptable. The image of an alternative future is also reflected in Brennan's work on Irish as it highlights efforts to challenge the predominance of English and give-albeit limited-visibility to Irish in the public sphere. Further, even Bolander's account draws the attention towards efforts that promote English as a language understood by all Ismaili and that may help to ensure the continuing existence of the community and its recognition within national and transnational contexts.

Thus, we understand discourses of commodification as both the result of the extension of neoliberal market logic to all domains of social life including language and in the same time as a means to challenge seemingly exclusive and inevitable dynamics of neoliberal capitalism and the legacies of previous regimes of dispossession and exploitation. In that respect, this special issue is not only meant as a continuation of the debate on language commodification, but also as a way to highlight where language-policy and -commodification intersect and continue to serve processes of normalization and ordering as well as emancipation and freedom.

\section{References}

Anderson, B. (1991). Imagined communities. London: Verso.

Bauman, R., \& Briggs, C. L. (2003). Voices of modernity: Language ideologies and the politics of inequality. New York: Cambridge University Press.

Bishop, H., Coupland, N., \& Garrett, P. (2005). Globalisation, advertising and language choice: Shifting values for Welsh and Welshness in Y Drych, 1851-2001. Multilingua, 24(4), 343-378.

Block, D. (forthcoming). What on earth is 'language commodification'? In S. Breidbach, L. Küster \& B. Schmenk (Eds.), Sloganizations in language education discourse. Bristol: Multilingual Matters.

Blommaert, J. (2009). A market of accents. Language Policy, 8(2), 243-259.

Blommaert, J., Kelly-Holmes, H., Lane, P., Leppänen, S., Moriarty, M., Pietikäinen, S., et al. (2009). Media, multilingualism and language policing: An introduction. Language Policy, 8(2), 203-207.

Cameron, D. (2000). Styling the worker: Gender and the commodification of language in the globalized service economy. Journal of Sociolinguistics, 4, 323-347.

Cameron, D. (2012). The commodification of language: English as a global commodity. In T. Nevalainen \& E. C. Traugott (Eds.), The Oxford handbook of the history of English (pp. 352-361). Oxford: Oxford University Press.

Cavanaugh, J., \& Shankar, S. (2014). Producing authenticity in global capitalism: Language, materiality, and value. American Anthropologist, 166(1), 51-64.

Del Percio, A., Flubacher, M., \& Duchêne, A. (2016). Language and political economy. In O. Garcia, N. Flores, \& M. Spotti (Eds.), Oxford handbook of language in society (pp. 55-75). New York: Oxford University Press. 
Duchêne, A. (2009). Marketing, management and performance: Multilingualism as commodity in a tourism call centre. Language Policy, 8, 27-50.

Duchêne, A. (2011). Néolibéralisme, inégalités sociales et plurilinguisme: l'exploitation des ressources langagières et des locuteurs. Langage et société, 136, 81-106.

Duchêne, A., \& Heller, M. (Eds.). (2012). Language in late capitalism: Pride and profit. New York: Routledge.

Fishman, J. A. (1991). Reversing language shift. Bristol: Mutlilingual Matters.

Foucault, M. (2000). Governmentality. In J. D. Faubion (Ed.), Essential works of foucault, power (Vol. 3, pp. 201-222). New York: New Press.

Foucault, M. (2007). Security, territory, population. London: Palgrave.

Grin, F. \& Vaillancourt, F. (2012). Multilingualism in economic activity. In C. Chapelle (Ed.), The Encyclopedia of Applied Linguistics Wiley. doi:10.1002/9781405198431.wbeal0808.

Heller, M., \& Duchêne, A. (2016). Treating language as an economic resource: Discourse, data, debates. In N. Coupland (Ed.), Sociolinguistics: Theoretical debates (pp. 139-156). New York: Cambridge University Press.

Holborow, M. (2015). Language and neoliberalism. London: Routledge.

Kelly-Holmes, H. (2005). Advertising as multilingual communication. Basingstoke: Palgrave MacMillan.

Kelly-Holmes, H. (2016). Theorizing the market in sociolinguistics. In N. Coupland (Ed.), Sociolinguistics: Theoretical debates. Cambridge: Cambridge University Press.

Martin-Rojo, L. (2016). Neoliberalism and linguistic governmentality. In O. Garcia, N. Flores, \& M. Spotti (Eds.), Oxford handbook of language in society. New York: Oxford University Press.

McGill, K. (2013). Political economy and language: A review of some recent literature. Journal of Linguistic Anthropology, 23(2), 84-101.

McNamara, T. (2012). Language assessments as Shibboleths: A Poststructuralist perspective. Applied Linguistics, 33(5), 564-581.

Pavlenko, A. (2017). Russian-friendly: How Russian became a commodity in Europe and beyond. In S. Muth \& L. Ryazanova-Clarke (Eds.), The commodification of Russian around the world (Special issue). International Journal of Bilingual Education and Bilingualism (Vol. 20(4), pp. 385-403).

Pietikäinen, S., \& Kelly-Holmes, H. (2013). Multilingualism and the periphery. Oxford: Oxford University Press.

Piller, I. (2007). English in Swiss tourism marketing. In C. Flores \& O. Grossegesse (Eds.), Wildern in luso-austro-deutschen Sprach- und Textgefilden: Festschrift zum 60. Geburtstag von Erwin Koller (pp. 57-73). Braga: CEHUM-Cent. Estudos Humanisticos.

Piller, I., \& Cho, J. (2013). Neoliberalism as language policy. Language in Society, 42(1), $23-44$.

Tan, P., \& Rubdy, R. (Eds.). (2008). Language as commodity: Global structures and local marketplaces. London: Continuum.

Wee, L. (2015). The language of organizational styling. Cambridge: Cambridge University Press.

Sebastian Muth is a senior researcher at the Institute of Multilingualism at the University of Fribourg, Switzerland. His current research addresses transnational healthcare and the global mobilty of patients and healthcare professionals with a special focus on language management and commodification. For this he has conducted ethnographic research in Switzerland, India, Lithuania and Russia. He has published in the International Journal of Bilingual Education and Bilingualism, the International Journal of the Sociology of Language as well as in Nationalities Papers.

Alfonso Del Percio is Lecturer in Applied Linguistics at UCL Institute of Education, University College London. He was trained in the fields of critical sociolinguistics and linguistic anthropology. His ethnographic and discourse analytic research deals with the intersection of language and political economy and focuses on language, migration and governmentality, the links between language, work, and social inequality. He also investigates the commodification of multilingualism and linguistic diversity under late capitalism. The outputs of Alfonso's research have appeared in books published by Routledge, Bloomsbury, and Suhrkamp as well as in peer-reviewed journals such as Pragmatics and Society, Social Semiotics, Signs and Society, Anthropologie et Sociétés, Applied Linguistics Review, and Language and Communication. 